\title{
Gangguan Kardiovaskular pada Infeksi COVID 19
}

\author{
Dian Yaniarti Hasanah', Siti Elkana Nauli², Paskariatne Probo Dewi ${ }^{3}$, Lita Dwi Suryani ${ }^{4}$, \\ Nana Maya Suryana ${ }^{5}$, Vebiona Kartini Prima Putri ${ }^{6}$, Wahyu Aditya ${ }^{7}$
}

I Departemen Kardiologi dan Kedokteran Vaskular, Universitas Indonesia, RS Jantung dan Pembuluh Darah Harapan Kita

2 Departemen Kardiologi dan Kedokteran Vaskular, RS Umum Daerah Tangerang

3 Departemen Kardiologi dan Kedokteran Vaskular, RSPAD Gatot Soebroto

4 Departemen Kardiologi dan Kedokteran Vaskular, RSUP Fatmawati

5 Departemen Kardiologi dan Kedokteran Vaskular, RSUP Persahabatan

6 Departemen Kardiologi dan Kedokteran Vaskular, RS Awal Bros Pekanbaru

7 Departemen Kardiologi dan Kedokteran Vaskular, RSPAD Gatot Soebroto

\section{Koresponden:}

Dian Yaniarti Hasanah

Departemen Kardiologi dan Kedokteran

Vaskular, Universitas Indonesia, RS Jantung dan Pembuluh Darah Harapan Kita

E-mail: deeboy2332@yahoo.com

\begin{abstract}
Abstrak
Severe acute respiratory syndrome coronavirus 2 (SARS-CoV-2) yang dikenal dengan COVID-19 adalah penyakit yang baru dan telah menyebar dengan cepat dari Wuhan (provinsi Hubei) ke provinsi lain di Cina dan seluruh dunia termasuk Indonesia. Secara umum, COVID-19 adalah penyakit akut yang bisa sembuh tetapi juga mematikan, dengan case fatality rate (CFR) sebesar 4\%. Spektrum klinis pneumonia COVID-19 berkisar dari kondisi ringan sampai dengan berat. COVID 19 diduga memiliki risiko potensiasi proses patofisiologi terhadap timbulnya komplikasi kardiak, dan telah diketahui bahwa mekanisme penyakit kardiovaskular serupa dengan mekanisme jalur imunologi. Penyakit kardiovaskular adalah komorbid terbanyak pada pasien COVID 19, SARS, dan MERS. Prevalensi diabetes mellitus (DM) dan penyakit kardiovaskular pada SARS adalah II\% dan 8\% dan membawa angka kematian meningkat 2 kali lipat. Pada kasus COVID 19, komorbid penyakit kardiovaskular lebih banyak menunjukkan kasus yang berat. Bagaimana mekanisme komorbid ini memperburuk keluaran pasien masih tidak jelas, namun beberapa hipotesisnya antara lain usia lanjut, gangguan sistem imun, peningkatan kadar ACE2 atau mungkin ada hubungan antara COVID 19 dengan penyakit kardiovaskular. Tinjauan pustaka ini akan menjelaskan berbagai gangguan kardiovaskular yang mungkin terjadi pada infeksi COVID 19 secara lebih mendalam.
\end{abstract}

(Indonesian J Cardiol. 2020;4 I:59-68)

Kata Kunci: COVID -19, Kardiovaskular, komorbid 


\section{Epidemiologi COVID I9}

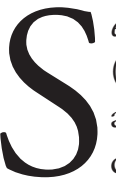

evere acute respiratory syndrome coronavirus 2 (SARS-CoV-2) yang dikenal dengan COVID-19 adalah penyakit yang baru dan telah menyebar dengan cepat dari Wuhan (provinsi Hubei) ke provinsi lain di Cina dan seluruh dunia termasuk Indonesia. Hingga 30 Maret 2020, jumlah pasien terkonfirmasi positif di Indonesia mencapai 1,414 kasus dengan 122 (8.6\%) pasien meninggal. Sementara di seluruh dunia mencapai 786,925 kasus dengan angka kematian sebesar 37,840 (4.5\%). ${ }^{(1)}$

Secara umum, COVID-19 adalah penyakit akut yang bisa sembuh tetapi juga mematikan, dengan case fatality rate (CFR) sebesar 4\%. Spektrum klinis pneumonia COVID-19 berkisar dari kondisi ringan sampai dengan berat. Onset penyakit yang berat dapat menyebabkan kematian karena kerusakan alveolar yang masif dan kegagalan pernapasan progresif. ${ }^{(1)}$

COVID 19 diduga memiliki risiko potensiasi proses patofisiologi terhadap timbulnya komplikasi kardiak, dan telah diketahui bahwa mekanisme penyakit kardiovaskular serupa dengan mekanisme jalur imunologi. Contohnya, usia adalah faktor risiko dominan pada penyakit kardiovaskular dan efek penuaan terhadap fungsi imun mungkin membawa dampak pada kerentanan dan derajat keparahan infeksi COVID 19. Adanya faktor risiko seperti diabetes dan dislipidemia berdampak pada fungsi imun, dan sebaliknya, gangguan regulasi sistem imun akan menyebabkan peningkatan insidens penyakit kardiovaskular. Oleh karenanya, penyakit kardiovaskular merupakan pertanda percepatan proses gangguan imunologi akibat usia dan berkorelasi secara tidak langsung dengan prognosis COVID 19.

Penyakit kardiovaskular adalah komorbid terbanyak pada pasien COVID 19, SARS, dan MERS. Prevalensi diabetes mellitus (DM) dan penyakit kardiovaskular pada SARS adalah $11 \%$ dan $8 \%$ dan membawa angka kematian meningkat 2 kali lipat. Pada kasus COVID 19, komorbid penyakit kardiovaskular lebih banyak menunjukkan kasus yang berat. Pada salah satu penelitian kohort 191 pasien dari Wuhan, Cina, komorbid ditemukan pada $48 \%$ pasien (pada yang meninggal $67 \%$ ), hipertensi pada $30 \%$ pasien $(48 \%$ meninggal), DM pada 19\% (31\% meninggal), dan penyakit kardiovaskular $8 \%$ ( $13 \%$ meninggal). Pada studi lain dari 138 pasien yang dirawat di rumah sakit dengan COVID 19, prevalensi komorbid tidak jauh berbeda (46\% dengan komorbid, 72\% memerlukan perawatan intensif). Bagaimana mekanisme komorbid ini memperburuk keluaran pasien masih tidak jelas, namun beberapa hipotesisnya antara lain usia lanjut, gangguan sistem imun, peningkatan kadar ACE2 atau mungkin ada hubungan antara COVID 19 dengan penyakit kardiovaskular. ${ }^{(2)}$

\section{Diagnosis COVID 19}

Gejala yang paling umum adalah demam (98\%), batuk (77\%), dan sesak nafas (63.5\%). Data dari Cina menunjukkan dari 52 pasien sakit kritis, 6 (11\%) orang tidak mengalami demam sampai 2-8 hari setelah timbulnya gejala terkait infeksi COVID-19. Durasi ratarata timbulnya gejala sampai terkonfirmasi pneumonia secara radiologis adalah 5 (IQR 3-7) hari. Durasi ratarata dari timbulnya gejala sampai masuk ICU adalah 9.5 (7-12.5) hari. ${ }^{(1)}$

Dari pemeriksaan darah tepi ditemukan limfopenia absolut, jumlah sel T CD4 dan CD8 perifer berkurang secara substansial, sementara statusnya hiperaktif, dibuktikan dengan tingginya HLA-DR (CD4 47\%) dan CD38 (CD8 39.4\%) dua kali lipat fraksi positif. Selain itu, terdapat peningkatan konsentrasi highly proinflammatory CCR6+ Th17 dalam sel T CD4. Selain itu, sel $\mathrm{T}$ CD8 ditemukan mengandung butiran sitotoksik konsentrasi tinggi, di mana 31.6\% sel positif perforin, $64.2 \%$ sel positif granulysin, dan $30.5 \%$ sel granulysin dan perforin positif keduanya. Hasil ini menunjukkan bahwa terlalu aktifnya sel $\mathrm{T}$ yang ditunjukkan oleh adanya peningkatan Th17 dan sitotoksisitas tinggi sel T CD8, menyebabkan kerusakan parah pada imunitas pasien.

Gambaran X-Ray menunjukkan adanya perkembangan pneumonia yang cepat dan beberapa perbedaan antara paru kiri dan kanan. Selain itu, jaringan hepar menunjukkan steatosis mikrovesikuler sedang dan aktivitas lobular ringan, tetapi tidak ada bukti konklusif untuk mendukung infeksi COVID-19 atau cedera hepar yang disebabkan karena obat sebagai penyebabnya. Tidak ada perubahan histologis yang terlihat pada jaringan miokard menunjukkan bahwa infeksi COVID 19 mungkin tidak secara langsung menyebabkan kerusakan jantung.

Pencitraan dengan CT scan yang sudah secara luas 
digunakan menunjukkan hasil yang abnormal pada $85 \%$ pasien sejak awal onset, dengan proporsi $75 \%$ terdapat keterlibatan kedua paru yang tampak sebagai area ground-glass opacity subpleura dan perifer, serta konsolidasi.

\section{COVID I9 dan Pneumonia}

Patofisiologi mendasar dari pneumonia berat akibat virus adalah ARDS. Laki-laki dan usia yang lebih tua (> 65 tahun) lebih mungkin untuk mengalami ARDS daripada wanita atau mereka yang berusia lebih muda. Sangat beralasan bahwa kematian pada 28 hari pertama pasien dengan pneumonia SARS-CoV-2 yang berat mirip dengan kematian akibat ARDS berat, yaitu mendekati $50 \%$. Pasien dengan riwayat penyakit serebrovaskular memiliki risiko lebih tinggi untuk mengalami kondisi kritis jika mereka terinfeksi SARS-CoV-2. ${ }^{(2)}$

\section{Efek Pneumonia Pada Sistem Kardiovaskular}

Selama beberapa dekade, para peneliti telah mencatat bahwa infeksi pernapasan akut, termasuk pneumonia, sering mendahului kejadian jantung akut. Hasil studi klinis menunjukkan bahwa pada pasien gagal jantung terjadi penurunan respons imunologis, dan bukti eksperimental menunjukkan bahwa kongesti paru dapat meningkatkan pertumbuhan bakteri umum seperti Streptococcus pneumoniae (pneumococcus) dan Staphylococcus aureus di paru-paru. Data epidemiologis juga menunjukkan bahwa riwayat gagal jantung adalah faktor risiko untuk terjadinya pneumonia. Oleh karena itu, hubungan sebab-akibat antara pneumonia dan gagal jantung mungkin dua arah.

Saat ini pemahaman tentang respons kardiovaskular terhadap infeksi termasuk pneumonia, berasal dari studi pasien yang sakit kritis dengan syok septik. Gangguan ini ditandai oleh ketidakmampuan vasokontriksi pembuluh darah perifer meskipun terjadi peningkatan konsentrasi katekolamin dan peningkatan aktivitas sistem renin-angiotensin-aldosteron; disfungsi sistolik dan diastolik miokard, terutama dari ventrikel kiri, dengan beberapa cidera miokard dimanifestasikan oleh peningkatan konsentrasi serum troponin tanpa adanya sindrom koroner akut; disfungsi otonom jantung; perubahan substansial dalam hemostasis, terutama didorong oleh aktivasi jalur koagulasi ekstrinsik dan penekanan fibrinolisis; gangguan fungsi hemostatik endotel pembuluh darah; dan disfungsi ginjal, yang mungkin timbul dari banyak proses sebelumnya atau gangguan ginjal primer lainnya (Gambar 1$).{ }^{(3)}$

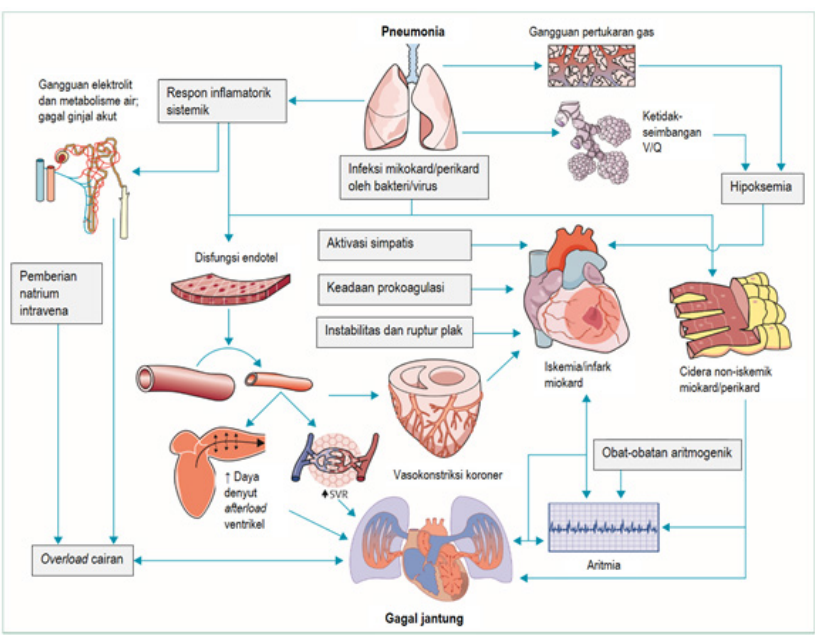

Gambar 1. Mekanisme patofisiologis yang berkontribusi pada komplikasi jantung pada pasien dengan pneumonia akut. (disadur dari ${ }^{(3)}$ )

\section{Efek COVID I 9 Terhadap Sistem Kardiovaskular}

SARS-CoV2 adalah family Coronaviridae, virus yang memiliki positive-sense RNA genome. Beberapa virus corona ini ditemukan pada kelelawar dan teori menunjukkan SARS-CoV2 dan virus corona lainnya menggunakan protein ACE2 untuk masuk kedalam sel. ACE2 adalah protein membran yang memiliki berbagai fungsi fisiologis. Protein ini banyak terdapat di sel alveolus yang merupakan pintu masuk virus di tubuh manusia. Setelah berikatan dengan ligan spesifik, SARSCoV2 memasuki sel melalui reseptor melalui proses endositosis seperti pada human immunodeficiency virus (HIV) . ${ }^{\text {(3) }}$ ACE2 juga berperan dalam proteksi paru-paru dan patogenesitas virus seperti tampak pada Gambar 2.(4)

Beberapa hipotesis mekanisme injuri miokard pada infeksi COVID 19, yaitu : ${ }^{(4)}$

1. Kerusakan yang diperantarai oleh ACE2

a. Peningkatan afinitas terhadap ACE2

b. Penurunan ekspresi ACE2

c. Disregulasi sisten renin angiotensin aldosterone

2. Injuri miokard akibat hipoksis

a. Stres oksidatif 


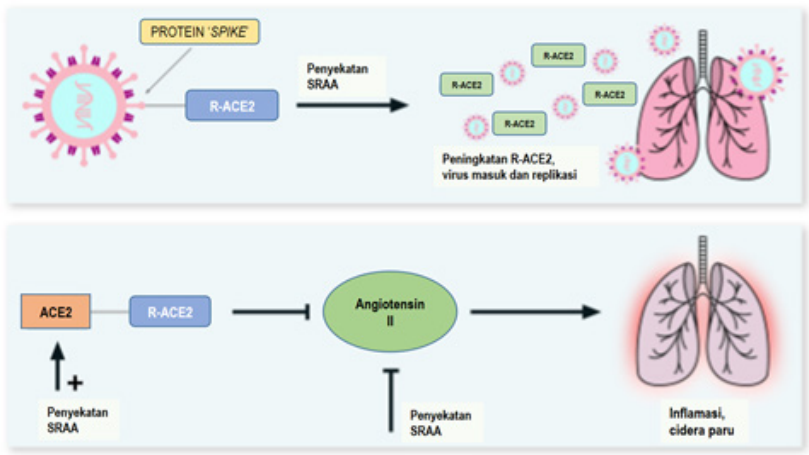

Gambar 2. Mekanisme Infeksi SARS-CoV2 dan Reseptor ACE2 (disadur dari ${ }^{(4)}$ )

b. Asidosis intrasel

c. Kerusakan mitokondria

3. Kerusakan mikrovaskular
a. Defek perfusi
b. Hiperpermeabilitas kapiler
c. Spasme pembuluh darah

4. Sindrom respon inflamasi sistemik
a. Badai sitokin
b. Disregulasi imunologi
c. Inflamasi yang tidak terkontrol

\section{Miokarditis Dan COVID I9}

Sindroma gangguan respirasi akut berat pada COVID 19 berpengaruh kepada miokard dan menyebabkan miokaditis. Beberapa laporan otopsi menunjukkan adanya infiltasi sel inflamasi mononuklear interstisial. Kasus miokarditis berat dengan penurunan fungsi sistolik ventrikel telah dilaporkan pada kasus COVID-19 melalui pemeriksan biomarker injuri jantung pada pasien yang dirawat. Injuri miokard ini berkaitan dengan infeksi dan/atau iskemia dan merupakan faktor prognostik yang penting pada kasus COVID-19. Shi et al melaporkan mortalitas pada 57 pasien yang dirawat di rumah sakit akibat COVID 19 (dari 416 pasien). Pada pasien-pasien ini, 10.6\% memiliki penyakit jantung koroner, $4.1 \%$ memiliki gagal jantung, dan 5.3\% memiliki penyakit serebrovaskular. Hampir 20\% pasien mengalami injuri kardiak yang ditandai dengan peningkatan hs-Troponin I lebih dari persentil 99. Pasien dengan hs-Troponin I biasanya lebih tua, dengan komorbid yang lebih banyak, dan memiliki kadar leukosit, $N$-terminal pro-brain natriuretic peptides, $C$ reactive protein, dan procalcitonin yang lebih tinggi, dengan hitung limfosit yang lebih rendah. Pasien dengan injuri kardiak memiliki insidens ARDS yang lebih tinggi (58.5\% vs $14.7 \%$; $\mathrm{P}$ <.001) dan angka mortalitas yang

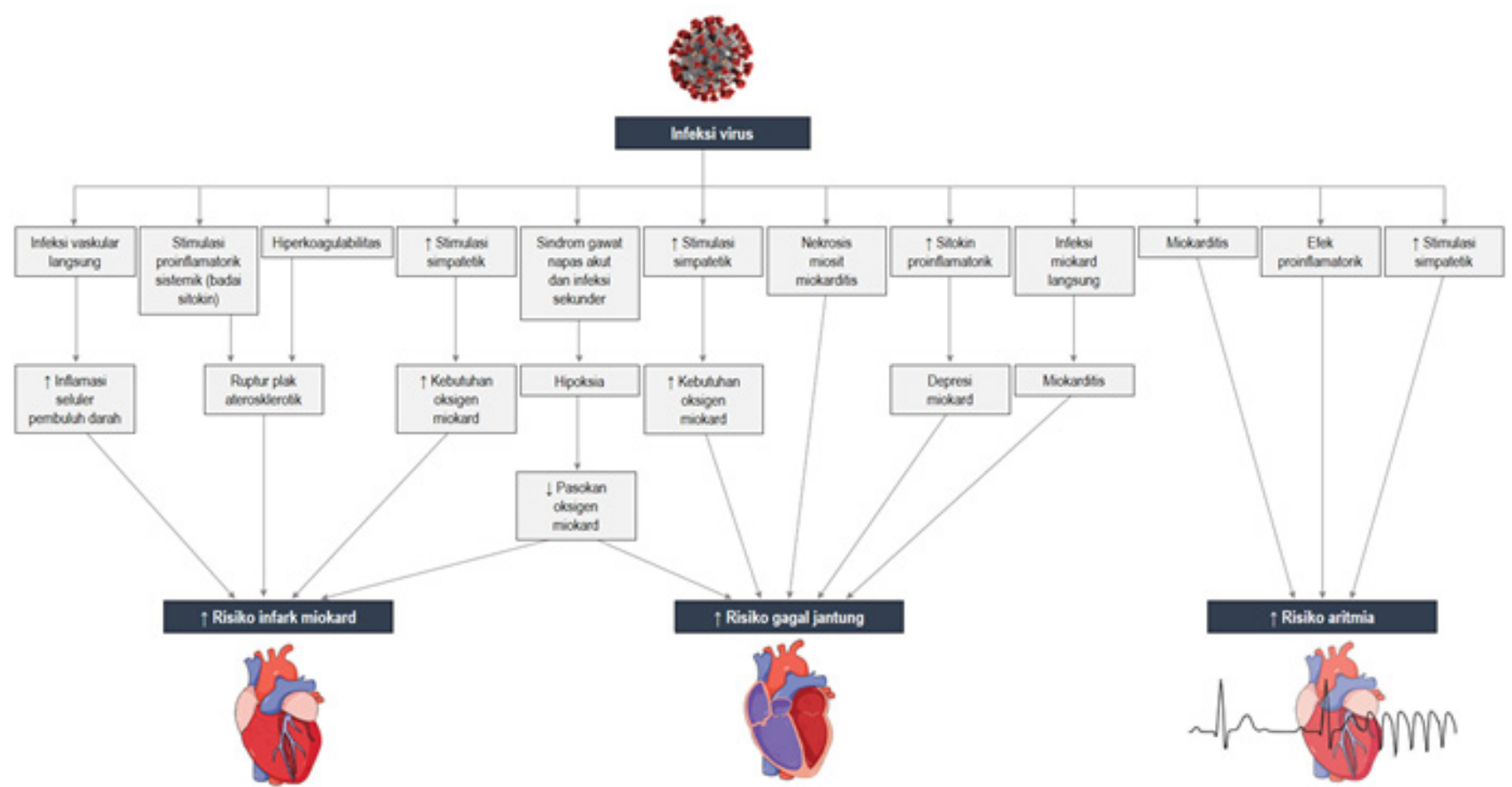

Gambar 3 Hipotesis mekanisme injuri miokard pada infeksi COVID 19 (disadur dari ${ }^{(5)}$ ) 
tinggi $(51.2 \%$ vs $4.5 \%$; $\mathrm{P}<.001)$ dibandingkan dengan pasien tanpa injuri miokard. Pada analisa multivariat, injuri kardiak dan ARDS tetap menjadi faktor prognosis angka mortalitas yang tinggi (HR 4.26 dan 7.89). Guo et al melaporkan beberapa faktor yang berhubungan dengan keluaran pasien COVID 19 yang dirawat di RS antara lain riwayat penyakit kardiovaskular (hipertensi, penyakit jantung koroner, atau kardiomiopati), ditemukan 28\% kasus injuri miokard akut (yang ditandai dengan peningkatan troponin $\mathrm{T}$ [TnT] lebih dari batas atas persentil 99, dan angka mortalitas lebih tinggi pada pasien yang memiliki nilai troponin $\mathrm{T}$ yang lebih tinggi $(59.6 \%$ vs $8.9 \%$; $\mathrm{P}<.001)$. Pasien dengan nilai troponin yang lebih tinggi biasanya lebih tua, lakilaki, dan disertai komorbid seperti hipertensi, penyakit jantung koroner, kardiomiopati, dan penyakit ginjal kronik, nilai leukosit, NT pro BNP, CRP, dan D-dimer yang lebih tinggi, dan nilai limfosit yang lebih rendah. Pasien dengan nilai TnT yang tinggi berisiko untuk timbulnya komplikasi ARDS, aritmia maligna, acute renal injury, dan koagulopati akut. Penggunaan obat seperti ACE inhibitor dan angiotensin II receptor blocker (ARB) pada pasien yang sudah menggunakannya, ternyata tidak berhubungan dengan mortalitas yang lebih tinggi walaupun kadar TnT tinggi. ${ }^{(1),(2),(4),(6)}$

Laporan dari NHC Cina, beberapa pasien dengan kasus palpitasi dan nyeri dada tanpa keluhan demam dan batuk, dan kasus miokarditis fulminant yang disertai syok kardiogenik insiden tidak banyak, namun mekanisme keterlibatan kardiak ini masih terus dipelajari. Salah satu mekanismenya adalah melalui ACE2, dimana SARS-CoV-2 akan masuk ke dalam sel melalui reseptor, namun ACE2 dianggap memiliki efek protektif terhadap injuri paru akut. Pada hewan coba, ikatan antara SARS-CoV dengan ACE2 menyebabkan downregulation ACE2, meningkatkan angiotensin II dan permeabilitas kapiler paru, menginduksi edema paru dan penurunan fungsi paru. Pemberian rekombinan ACE 237 dan Losartan dapat mengurangi injuri paru. Studi losartan sedang dikerjakan untuk pasien COVID 19. Penghentian obat ACE inhibitor, Angiotensin Receptor Blocker (ARB), dan antagonis sistem renin angiotensin aldosterone tidak dianjurkan karena bukti ilmiah masih belum ada. ${ }^{(5)}$

Beberapa sequel paska infeksi COVID 19 antara lain : aritmia, miokarditis, sindrom koroner akut, tromboemboli vena, syok kardiogenik, dan gagal jantung (Gambar 4) $)^{(4)}$

\section{Aritmia Dan Henti Jantung}

Aritmia merupakan salah satu manifestasi kardiovaskular pada infeksi COVID-19. Pasien mengeluhkan palpitasi pada $7.3 \%$ kasus. Pada pasien
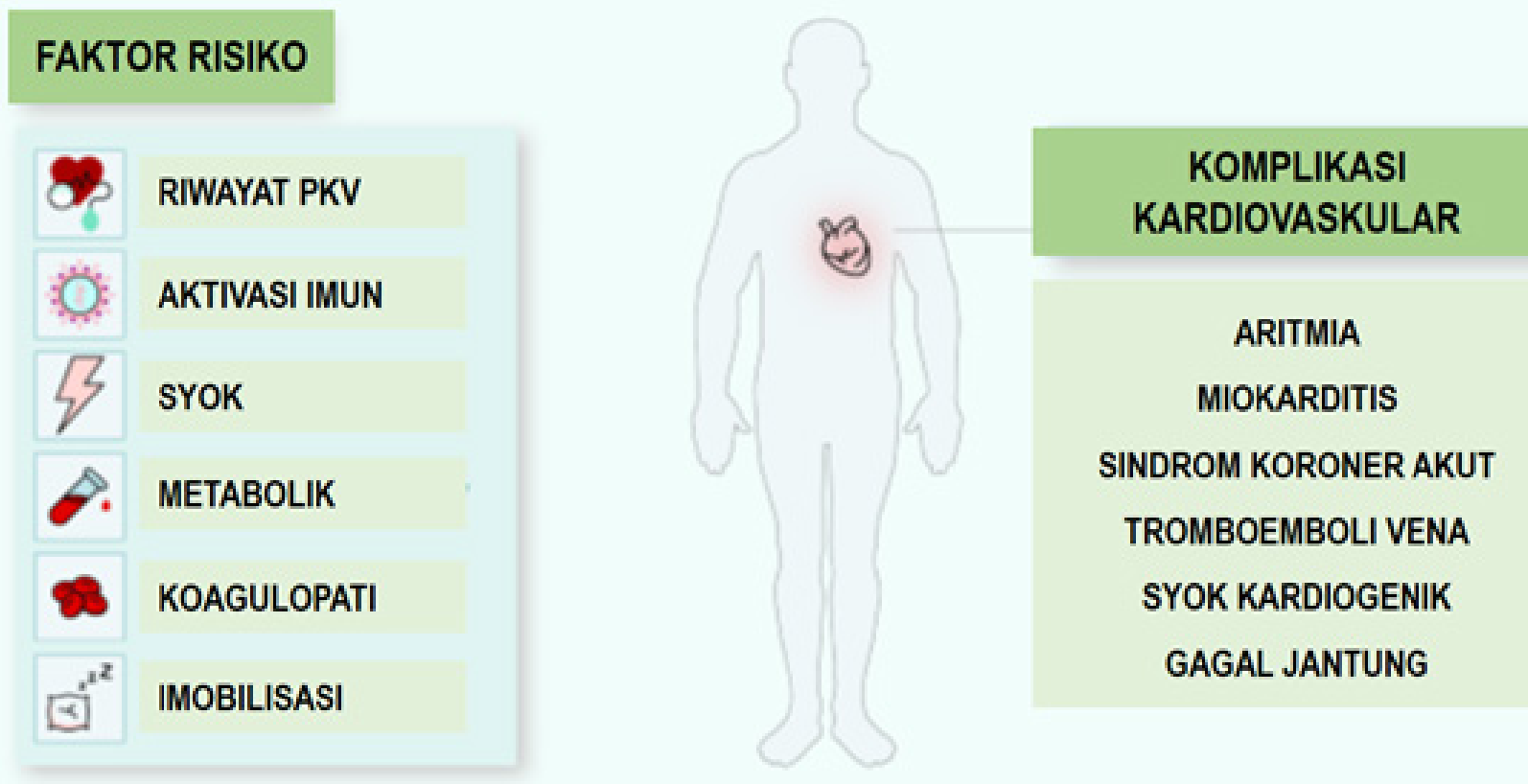

Gambar 4 Faktor risiko dan komplikasi kardiovaskular pada Infeksi SARS-CoV-2 (disadur dari ${ }^{(4)}$ ) 
yang dirawat intensif, keluhan ini timbul pada $44.4 \%$ pasien. Tingginya kejadian aritmia mungkin menjadi bagian dari gangguan metabolisme, hipoksia, neurohumoral atau stress inflamasi dan kejadian takiaritmia maligna mungkin timbul pada pasien dengan miokarditis. ${ }^{(4),(6)}$

\section{Kardiomiopati Dan Gagal Jantung}

Zhou et al melaporkan kejadian gagal jantung pada 23\% pasien COVID-19. Gagal jantung lebih banyak ditemukan daripada disfungsi renal dan memiliki angka mortalitas yang sangat tinggi (51.9\% vs. $11.7 \%)$. Gagal jantung kanan dan hipertensi paru akibat gangguan parenkim paru dan ARDS juga bisa terjadi. ${ }^{(4),(6)}$

\section{Syok Kardiogenik}

Presentasi klinis utama infeksi COVID-19 adalah gangguan saluran nafas yang dapat berkembang menjadi ARDS dengan gambaran ground-glass opacities pada pencitraan dan hipoksemia. Gambaran serupa bisa tampak pada kasus yang disertai edema paru kardiogenik. Pada kondisi ini, nilai brain natriuretic peptide (BNP) dan ekokardiografi dapat membantu menegakkan diagnosis, namun pada kasus yang meragukan pemeriksaan swan ganz dapat dipertimbangkan untuk menilai tekanan pengisian, cardiac output, dan sebagai panduan tatalaksana ARDS dan syok kardiogenik seperti extracorporeal membranous oxygenation (ECMO). Pada kondisi berat dimana terjadi ARDS dan necrotizing pneumonias, prognosis ECMO tetap jelek (angka mortalitas 83,3\%). ${ }^{(4),(6)}$

\section{Tromboemboli Vena}

Risiko terjadinya tromboemboli pada infeksi COVID-19 diduga akibat abnormalitas faktor koagulasi pada kondisi infeksi yang berat. Peningkatan kadar D-dimer $(>1 \mathrm{~g} / \mathrm{L})$ berkorelasi kuat dengan mortalitas (OR 18.4 95\% CI 2.6-128.6, p=0.003) akibat disseminated intravascular coagulation (DIC). Faktor lain yang mempermudah timbulnya tromboemboli adalah imobilisasi, inflamasi vaskular yang menyebabkan kondisi hiperkoagulasi dan disfungsi endotel yang dipicu oleh hipoksia atau hemodinamik yang tidak stabil. Terdapat interaksi beberapa obat antivirus dengan antikoagulan oral, low molecular weight heparin (LMWH), atau unfractionated heparin sehingga profilaksis mekanik lebih diutamakan pada pasien yang dirawat di RS sebagai pencegahan tromboemboli vena. (4),(6)

\section{Tatalaksana COVID I9 Dengan Gangguan Kar- diovaskular Dan Implikasinya}

Interaksi yang tampak pada kombinasi obat antivirus dengan obat-obat kardiovaskular umumnya bersifat potensiasi efek samping kardiovaskular, contohnya lopinavir/ritonavir dapat menyebabkan pemanjangan interval QT dan PR terutama pada pasien dengan long $Q T$ syndrome atau pasien yang memiliki gangguan konduksi atau potensiasi dengan obat jantung yang memperpanjang interval seperti amiodarone.

Ribavirin tidak memiliki efek toksik kardiovaskular. Ribavirin dan lopinavir/ritonavir memiliki efek potensiasi dengan antikoagulan dengan meingkatkan efek obat antikoagulan, sehingga dosis antikoagulan oral (apixaban dan rivaroxaban) harus dikurangi. Lopinavir/ ritonavir mempengaruhi aktivitas $\mathrm{P} 2 \mathrm{Y} 12$ inhibitor melalui inhibisi CYP3A4, menyebabkan turunnya konsentrasi metabolit aktif dari clopidogrel dan prasugrel dalam serum dan meningkatnya kadar ticagrelor dalam serum. Oleh karenanya pada kasus yang memerlukan pengobatan lopinavir/ritonavir, penggunaan ticagrelor harus dihentikan karena menyebabkan perdarahan. Beberapa studi menunjukkan efek inhibisi platelet yang kurang baik dengan penggunaan clopidogrel, sehingga pada kasus pemakaian antivirus yang memerlukan antiplatelet maka prasugrel merupakan rekomendasi utama. Metabolit inihibitor P2Y12 intravena seperti cangrelor lebih aman digunakan karena obat ini tidak terkait dengan metabolism hepar. $H M G-C o A$ reductase inhibitors (statin) memiliki efek potensiasi dengan lopinavir/ritonavir dan dapat menyebabkan miopati. Kombinasi lovastatin atau simvastatin dengan lopinavir/ritonavir merupakan kontraindikasi mutlak karena dapat menyebabkan rabdomiolisis. Statin lain seperti atorvastatin dan rosuvastatin, harus diberikan dengan dosis kecil untuk menghindari efek samping rabdomiolisis apabila dikombinasi dengan lopinavir/ ritonavir. ${ }^{(2),(4)}$

Remdesivir adalah golongan antivirus yang digunakan pada epidemik Ebola dan sedang dipelajari bagaimana efikasinya pada kasus COVID-19. Obat ini tidak menimbulkan hipotensi dan henti jantung pada penggunaannya. 
Terapi lain seperti Klorokuin, yang biasa digunakan sebagai obat malaria dapat menghambat infeksi virus dengan meningkatkan $\mathrm{pH}$ endosomal yang diperlukan virus untuk melakukan fusi dengan sel, dan secara in vitro mampu menghambat aktivitas COVID 19. Klorokuin dan hidroklorokuin memiliki efek toksisitas terhadap miokard. Beberapa faktor yang menyebabkan toksisitas ini adalah penggunaan jangka panjang (> 3 bulan), dosis tinggi, riwayat penyakit jantung, dan disfungsi ginjal. Toksisitas klorokuin menyebabkan kardiomiopati restriktif dan dilatasi, gangguan konduksi akibat inhibisi enzim lisosom intrasel dari miosit. Efek klorokuin terhadap inhibisi CYP2D6, penggunaan $\beta$-blocker yang memiliki jalur metabolism yang sama (seperti metoprolol, carvedilol, propranolol, dan labetalol) dapat meningkatkan efek penghambatan reseptor $\beta$ terhadap laju nadi dan tekanan darah. Antivirus dan klorokuin dapat meningkatkan kejadian torsade de pointes pada pasien dengan gangguan elektrolit dan pasien yang menggunakan obat yang

Tabel 1. Terapi antivirus pada COVID 19 : Interaksi Kardiovaskular dan Toksisitas ${ }^{(4)}$

\begin{tabular}{|c|c|c|c|}
\hline & Interaksi & Mekanisme interaksi & Catatan \\
\hline Ribavirin & Warfarin & Tidak diketahui & Monitor INR \\
\hline \multirow[t]{6}{*}{ Lopinavir/ritonavir } & $\begin{array}{l}\text { Apixaban } \\
\text { Rivaroxaban }\end{array}$ & $\begin{array}{l}\text { Inhibisi CYP3A4 } \\
\text { Gunakan dosis apixaban 50\% (jangan } \\
\text { berikan dosis 2,5 mg) } \\
\text { Jangan gunakan rivaroxaban }\end{array}$ & $\begin{array}{l}\text { Hati-hati menggunakan dabigatran } \\
\text { dan warfarin }\end{array}$ \\
\hline & $\begin{array}{l}\text { Clopidogrel } \\
\text { Ticagrelor }\end{array}$ & $\begin{array}{l}\text { Inhibisi CYP3A4 } \\
\text { Menurunkan efek clopidogrel } \\
\text { Potensiasi efek ticagrelor }\end{array}$ & $\begin{array}{l}\text { Hindari ticagrelor } \\
\text { Prasugrel dapat dipertimbangkan } \\
\text { Pertimbangkan pemeriksaan fungsi } \\
\text { platelet }\end{array}$ \\
\hline & $\begin{array}{l}\text { Statin : } \\
\text { Atorvastatin } \\
\text { Rosuvastatin }\end{array}$ & $\begin{array}{l}\text { Inhibisi OATTP 1B1 dan BCRT } \\
\text { Dosis maksimal rosuvastatin } 10 \mathrm{mg} / \text { hari }\end{array}$ & $\begin{array}{l}\text { Mulai dengan dosis kecil pada } \\
\text { atorvastatin dan rosuvastatin }\end{array}$ \\
\hline & $\begin{array}{l}\text { Lovastatin } \\
\text { Simvastatin }\end{array}$ & $\begin{array}{l}\text { Inhibisi CYP3A4 } \\
\text { Dosis maksimal atorvastatin } 20 \mathrm{mg} / \text { hari } \\
\text { Hindari lovastatin dan simvastatin }\end{array}$ & $\begin{array}{l}\text { Alternatif : pravastatin dan } \\
\text { pitavastatin }\end{array}$ \\
\hline & $\begin{array}{l}\text { Antiaritmia : } \\
\text { Obat yang memperpanjang } \\
\text { interval QT }\end{array}$ & Inhibisi P-glikoprotein & Monitor kadar digoksin \\
\hline & Digoksin & & \\
\hline Remdesevir & Analog nukelotide & Tidak diketahui & Tidak diketahui \\
\hline \multirow[t]{3}{*}{$\begin{array}{l}\text { Klorokuin/ } \\
\text { hidroksiklorokuin }\end{array}$} & $\begin{array}{l}\text { B-blocker: } \\
\text { Metoprolol, carvedilol, } \\
\text { propranolol, labetalol }\end{array}$ & $\begin{array}{l}\text { Inhibisi CYP2D6 } \\
\text { Kurangi dosis B-blocker }\end{array}$ & $\begin{array}{l}\text { Gunakan hati-hati dalam kombinasi } \\
\text { dengan antiaritmia }\end{array}$ \\
\hline & $\begin{array}{l}\text { Antiaritmia : } \\
\text { Obat yang memperpanjang } \\
\text { interval QT }\end{array}$ & $\begin{array}{l}\text { Inhibisi P-glikoprotein } \\
\text { Monitor kadar digoksin dalam darah }\end{array}$ & \\
\hline & Digoksin & & \\
\hline Fingolimod & $\begin{array}{l}\text { Obat yang mencetuskan } \\
\text { bradikardia: } \\
\text { B-blocker, calcium channel } \\
\text { blocker, ivabradine }\end{array}$ & $\begin{array}{l}\text { Inhibisi limfosit melalui regulasi sfingosin-1 } \\
\text { fosfat } \\
\text { Jangan diberikan dengan kombinasi } \\
\text { antiaritmia kelas Ia dan kelas III }\end{array}$ & $\begin{array}{l}\text { Gunakan hati-hati dalam } \\
\text { kombinasi dengan antiaritmia yang } \\
\text { menyebabkan pemanjangan interval } \\
\text { QT }\end{array}$ \\
\hline Metilprednisolon & Antikoagulan : warfarin & Tidak diketahui & Monitor INR \\
\hline
\end{tabular}


Indonesian Journal of Cardiology

Tabel 2. Interaksi kardiovaskular dan toksisitas ${ }^{(4)}$

\begin{tabular}{|c|c|c|c|}
\hline & Mekanisme & Interaksi obat KV & Efek samping KV \\
\hline Ribavirin & $\begin{array}{l}\text { Menghambat replikasi DNA } \\
\text { dan RNA virus }\end{array}$ & Antikoagulan & Tidak diketahui \\
\hline Lopinavir/ritonavir & $\begin{array}{l}\text { Inhibisi protease (lopinavir) } \\
\text { Menghambat CYP3A, } \\
\text { meningkatkan kadar lopinavir } \\
\text { (ritonavir) }\end{array}$ & $\begin{array}{l}\text { Antiplatelet } \\
\text { Antikoagulan } \\
\text { Statin } \\
\text { Antiaritmia }\end{array}$ & $\begin{array}{l}\text { Gangguan konduksi : } \\
\text { - } \quad \text { Memperpanjang interval QT } \\
\text { - } \quad \text { AV blok } \\
\text { - } \quad \text { Torsade de pointes }\end{array}$ \\
\hline Remdesevir & Analog nukelotide & Tidak diketahui & Tidak diketahui \\
\hline Oseltamivir & $\begin{array}{l}\text { antivirus golongan } \\
\text { neuraminidase inhibitor } \\
\text { (NAI) }\end{array}$ & $\begin{array}{l}\text { Antiplatelet } \\
\text { Warfarin }\end{array}$ & Minimal \\
\hline Bevacizumab & Inhibisi VEGF & Tidak diketahui & $\begin{array}{ll}\text { - } & \text { Toksik terhadap miokard } \\
\text { - } & \text { Menyebabkan eksaserbasi akut gagal jantung } \\
\text { - } & \text { Hipotensi berat } \\
\text { - } & \text { Tromboemboli }\end{array}$ \\
\hline $\begin{array}{l}\text { Klorokuin/ } \\
\text { hidroksiklorokuin }\end{array}$ & $\begin{array}{l}\text { Mengubah pH endosomal saat } \\
\text { fusi virus }\end{array}$ & Antiaritmia & $\begin{array}{l}\text { - Toksik terhadap miokard } \\
\text { - Menyebabkan eksaserbasi akut gagal jantung } \\
\text { - Mengganggu konduksi atriventrikular, torsade } \\
\text { de pointes, takikardi ventrikel, fibrilasi } \\
\text { ventrikel, bundle branch block }\end{array}$ \\
\hline Eculizumab & Inhibisi aktivasi komplemen & Tidak diketahui & $\begin{array}{ll}\text { - } & \text { Hipertensi } \\
\text { - } & \text { Takikardia } \\
\text { - } & \text { Edema perifer }\end{array}$ \\
\hline Fingolimod & $\begin{array}{l}\text { Inhibisi limfosit melalui } \\
\text { regulasi sfingosin-1 fosfat }\end{array}$ & Antiaritmia & $\begin{array}{ll}\text { - } & \text { Hipertensi } \\
\text { - } & \text { Blok atrioventricular } \\
\text { - } & \text { Bradikardia } \\
\text { - } & \text { Pemanjangan interval QT Kontraindikasi pada } \\
& \text { sindrom koroner akut, gagal jantung, stroke }\end{array}$ \\
\hline Interferon & Aktivasi sistem imun & Tidak diketahui & $\begin{array}{l}\text { - Toksisitas miokard } \\
\text { - Eksaserbasi gagal jantung } \\
\text { - Hipotensi, aritmia, kardiomiopati, infark } \\
\text { miokard }\end{array}$ \\
\hline Pirfenidon & $\begin{array}{l}\text { Mengurangi fibrosis } \\
\text { Inhibisi IL-1 } \beta \text { dan IL-4 } \\
\text { Mengurangi badai sitokin }\end{array}$ & Tidak diketahui & Tidak diketahui \\
\hline Metilprednisolon & $\begin{array}{l}\text { Mengubah ekspresi gen untuk } \\
\text { menurunkan inflamasi }\end{array}$ & Antikoagulan & $\begin{array}{ll}\text { - } & \text { Retensi cairan } \\
\text { - } & \text { Hipertensi } \\
\text { - } & \text { Gangguan elektrolit }\end{array}$ \\
\hline Tocilizumab & Inhibisi reseptor IL-6 & Tidak diketahui & $\begin{array}{l}\text { - Hipertensi } \\
\text { - Meningkatkan kadar kolesterol } \\
\text { - Efek pemanjangan interval QT belum } \\
\text { diketahui }\end{array}$ \\
\hline
\end{tabular}




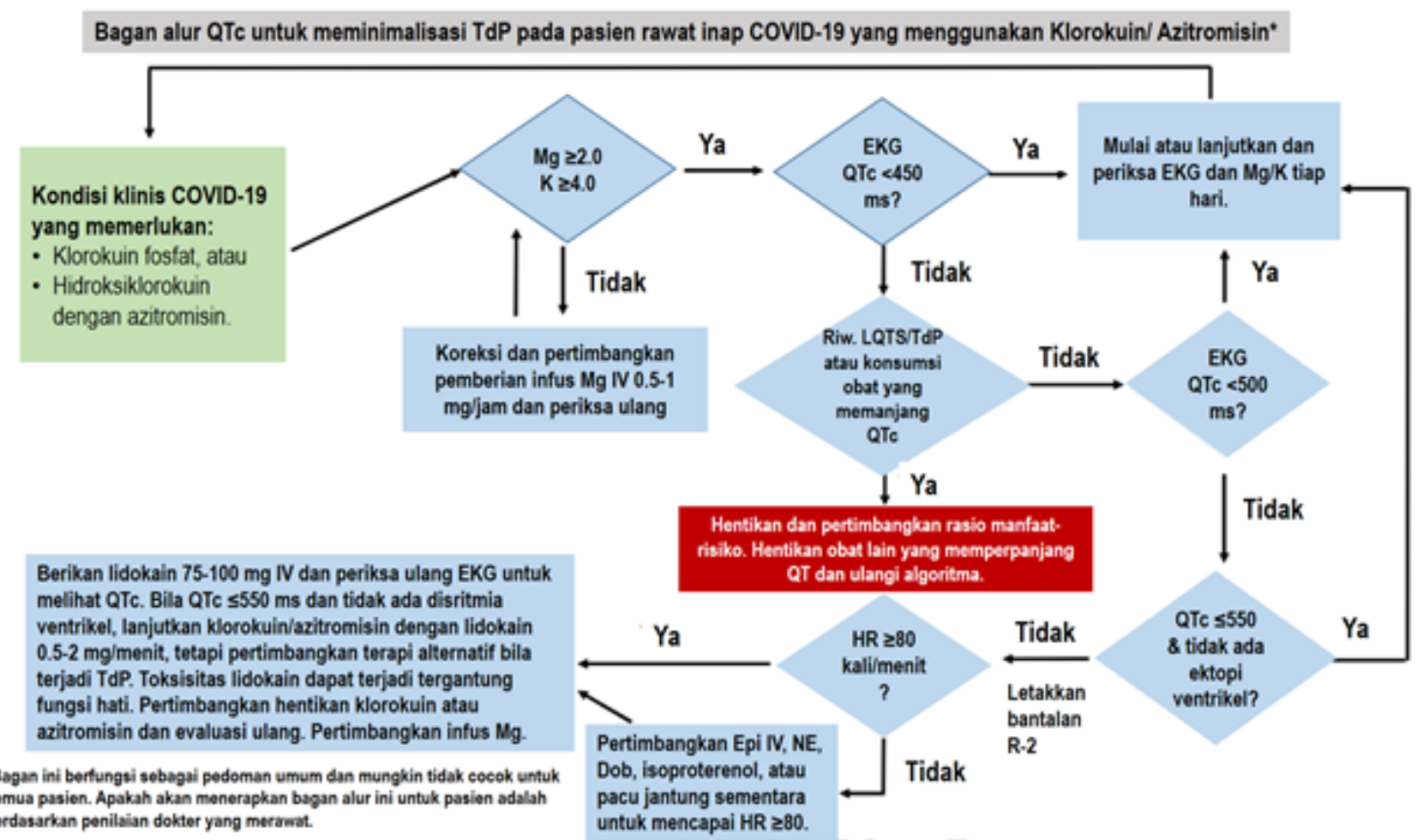

Singkatan : Mg : Serum Magnesium ; K : Serum Potassium ; ms : milliseconds ; LQTS : Long QT Syndrome ; TdP : Torsades de Pointes; IV : intravena ; Epi : Epinefrin ; NE : Norefinefrin; Dob : Dobutamin

Gambar 5. Flowchart Pemantauan QTc pada Pemberian Klorokuin, Hidroksiklorokuin kombinasi dengan Azitromisin (disadur dari reff ${ }^{(9)}$ )

mempengaruhi interval QT. Flowchart pemantauan QTc untuk meminimalisir kejadian torsade de pointes pada pasien yang mendapatkan klorokuin dapat dilihat pada gambar 5.

Metilprednisolon merupakan salah satu obat yang digunakan pada COVID 19 dengan komplikasi ARDS, obat ini telah diketahui memiliki efek retensi cairan, gangguan elektrolit, dan hipertensi, serta memiliki interaksi dengan warfarin melalui mekanisme yang belum diketahui.

\section{ACE2 dan implikasi terapi}

Reseptor ACE2 merupakan tempat masuknya SARS-CoV2 ke dalam sel alveoli. Beberapa data memperkirakan penggunaan ACE inhibitors (ACEi) dan angiotensin receptor blockers (ARB) dapat meng"upregulate" ACE2 sehingga meningkatkan kerentanan sel terhadap virus. Di studi lain menunjukkan bahwa ACEi/ARB bermanfaat sebagai proteksi paru dengan menghambat angiotensin I. Namun secara umum, belum cukup data yang menunjukkan bagaimana kaitan pemakaian ACEi/ARB dengan severitas COVID-19. (7),(8)

\section{Ringkasan}

SARS-COV-2 tidak hanya menyebabkan pneumonia, namun juga memiliki implikasi mayor terhadap sistem kardiovaskular. Pasien yang memiliki faktor risiko maupun penyakit kardiovaskular merupakan populasi yang berisiko tinggi ketika menderita COVID 19. Selain itu, pasien COVID 19 yang mengalami injuri miokard juga akan memiliki risiko morbiditas dan mortalitas yang lebih tinggi saat perawatan. Selain terjadinya injuri miokard, gangguan kardiovaskular lain yang dapat timbul antara lain komplikasi trombotik arteri (dengan presentasi sindrom koroner akut), komplikasi tromboemboli vena, miokarditis, aritmia, gagal jantung, hingga syok kardiogenik. Beberapa terapi yang digunakan pada infeksi COVID 19 juga 
diketahui dapat menyebabkan toksisitas pada sistem kardiovaskular, sehingga dibutuhkan pemantauan dalam pemberiannya untuk meminimalisir terjadinya efek samping yang tidak diinginkan.

\section{Conflict of Interest}

None

\section{Consent for Publication}

All authors consented for publication at the Indonesian Journal of Cardiology

\section{Sources of funding}

None

\section{Ethical clearance}

Not applicable

\section{Copyright/ permission for figures}

We the Authors of this manuscript declare that we have received the proper permission regarding the use of figures/images/illustrations from their Original Authors

\section{Referensi}

1. Yang X, Yu Y, Xu J, Shu H, Liu H, Wu Y, et al. Clinical course and outcomes of critically ill patients with SARS-CoV-2 pneumonia in Wuhan, China: a single-centered, retrospective, observational study. The Lancet Respiratory Medicine. 2020.

2. Clerkin KJ, Fried JA, Raikhelkar J, Sayer G, Griffin JM, Masoumi A, et al. Coronavirus Disease 2019 (COVID-19) and Cardiovascular Disease. Circulation. 2020.

3. Corrales-Medina VF, Musher DM, Shachkina S, Chirinos JA. Acutepneumonia and the cardiovascular system. The Lancet. 2013;381(9865):496-505.

4. Driggin E, Madhavan MV, Bikdeli B, Chuich T, Laracy J, Bondi-Zoccai G, et al. Cardiovascular considerations for patients, health care workers, and health systems during the coronavirus disease 2019 (COVID-19) pandemic. Journal of the American College of Cardiology. 2020.
5. Madjid M, Safavi-Naeini P, Solomon SD, Vardeny O. Potential Effects of Coronaviruses on the Cardiovascular System: A Review. JAMA cardiology. 2020.

6. Zheng Y-Y, Ma Y-T, Zhang J-Y, Xie X. COVID-19 and the cardiovascular system. Nature Reviews Cardiology. 2020:1-2.

7. Xiong T-Y, Redwood S, Prendergast B, Chen M. Coronaviruses and the cardiovascular system: acute and long-term implications. European Heart Journal. 2020.

8. Mehra MR, Ruschitzka F. COVID-19 Illness and Heart Failure: A Missing Link? : JACC: Heart Failure; 2020.

9. Mitra RL GS, Epstein, LM. An algorithm for managing QT prolongation in Coronavirus Disease 2019 (COVID-19) patients treated with either chloroquine or hydroxychloroquine in conjunction with azithromycin: Possible benefits of intravenous lidocaine. Elsevier. 2020. 